\title{
(1) crances \\ Poor balance, bilateral upper limb phocomelia, no previous exercise: a challenging combination for fall prevention in a middle-aged thalidomide survivor
}

\author{
Dee Morrison
}

The Thalidomide Trust, St Neots, UK

Correspondence to Dr Dee Morrison; dee.morrison@thalidomidetrust. org

Accepted 26 December 2019

Check for updates

(C) BMJ Publishing Group Limited 2020. Re-use permitted under CC BY-NC. No commercial re-use. See rights and permissions. Published by BMJ.

To cite: Morrison D. BMJ Case Rep 2020;13:e231345. doi:10.1136/bcr-2019231345

\section{SUMMARY}

Poor balance and falls pose substantial risks to health and well-being. Thalidomide survivors with arm defects have an additional risk being unable to protect themselves in a fall. Generic exercise information to improve strength and balance is increasingly available to the elderly. However, disability can carry a lifetime risk. Identifying and correcting underlying musculoskeletal issues, correction of gait abnormalities together with establishing an appropriate exercise routine that is affordable, convenient and fun should improve outcomes at any stage of adult life. This can be challenging, not least in those who have never previously exercised and who are now middle aged or older. The Thalidomide Trust piloted focused support for a middle-aged thalidomide survivor with bilateral radial club hands and increasing balance issues who had never previously exercised. This met with great success improving his strength, balance, gait and posture together with ensuring an established exercise routine to maintain the improvement.

\section{BACKGROUND}

In the late 1950 s and early 1960s thalidomide (when given in the sensitive time period of pregnancy) resulted in babies born with thalidomide embryopathy and many with varying degrees of shortening of the upper limbs. The Thalidomide Trust has 464 beneficiaries now in their mid to late 50 s with musculoskeletal issues, early arthritis and compression neuropathies complicating the original damage. ${ }^{12}$ As anecdotal reports of balance issues and falls were increasing, the Thalidomide Trust undertook its own research to explore the issues further. ${ }^{3}$ One-third of the respondents reported falls since childhood but over a half reported they had only started to fall in their 40s and 50s; as thalidomide can cause varying degrees of external ear abnormalities together with inner ear damage, it has been postulated that undiagnosed inner ear damage might be a contributory factor to the increasingly poor balance. Some of the falls had resulted in severe injury due to their reduced upper limbs and inability to save themselves as they fall. This in turn had resulted in a temporary substantial increase of their disability and dependence on social care together with the usual loss of confidence resulting from such a fall. Despite Trust initiatives, such as holding seminars to help motivate beneficiaries to eat healthily and exercise, tailoring written information to the needs of the group such as a leaflet on balance and falls and making available national information on the importance of exercise alongside beneficiaries own success stories on how they exercised, many were still not undertaking any programme to help reduce their falls. ${ }^{4}$ The Trust determined that more focused help and support was needed to pilot initial physiotherapy progressing on to establishing an exercise routine.

When a beneficiary, a thalidomide survivor in his mid-50s with severe upper limb shortening and an unequal leg length, phoned the Trust helpline with concerns regarding his balance and fear of falling, the Trust decided to work with him to see how they could help. A video crew was sent to follow progress.

\section{CASE PRESENTATION}

Prior to approaching the Trust, the beneficiary had never exercised before. He had attended a Trust weekend on healthy eating and exercise but had subsequently not taken it forward. ${ }^{6}$ Though he had not actually fallen, he was suffering with low back pain, together with balance issues such as difficulty going up and down stairs, difficulty using a hand rail to support this activity because of the length of his arms and difficulty getting on and off buses (figure 1). He lived in Glasgow and with his permission the Trust approached a local physiotherapist whose website actively promoted help with balance and falls. The Trust discussed with the physiotherapist issues common within the group and requested certain objectives to be measures of success such as the ability to go up and down stairs, improved balance and ability to get up after a fall together with a reduction of overall pain levels. A priority would be that the beneficiary be supported to find an exercise he could enjoy once physiotherapy had finished and for a routine to be encouraged to be developed (video 1).

\section{TREATMENT}

After the initial assessment the physiotherapist noted the beneficiary's unequal leg length and felt it was contributing to his back pain. The Trust, therefore, supported the request for a separate biomechanical gait assessment and the beneficiary received an insole for the first time in his life. Once this was fitted, the therapy began with the beneficiary receiving treatment and being shown exercises 


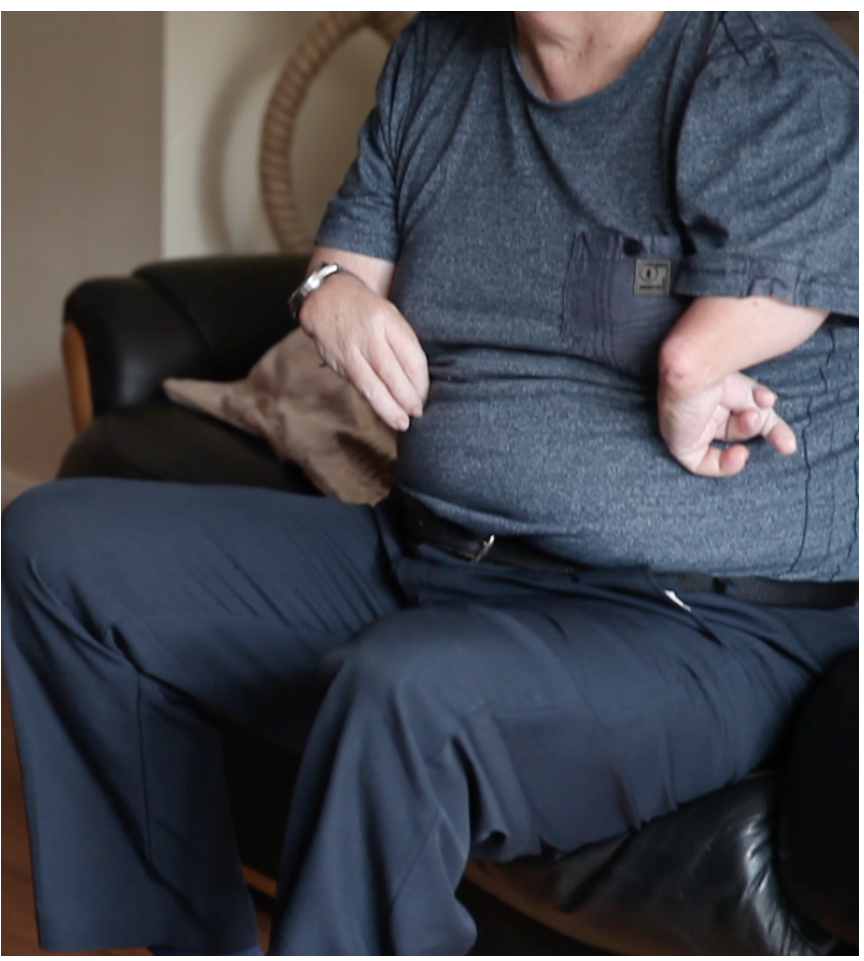

Figure 1 Before treatment.

to be worked on both in the sessions and individually at home. The exercises were chosen carefully so they could be undertaken without gym equipments and with consideration of his level of disability. The physiotherapist reported the beneficiary to be an ideal client and the relationship between therapist and client developed well. In total he received 15 physiotherapy treatment sessions spread over a period of 7 months.

As in table 1 , the sternal nudge test was initially very low and he needed a lot of work to strengthen the legs with sit to stand practice, step-ups/down/lateral as well as single leg stance work. Some balance and balance righting reactions were improved to raise confidence together with his ability to turn. As per the majority of frequent fallers, he had the habit of pivoting/spinning on his feet when turning instead of lifting and stepping his feet. The beneficiary needed education around the bad movement behaviour and much repeated practice doing step round turns in different situation/scenarios to improve this. His ability to take an 'effective step' was improved with exercises like lunges, high knee march, step up and overs, cross over steps, side lunges and gait re-education. He was no different than the 'normal'

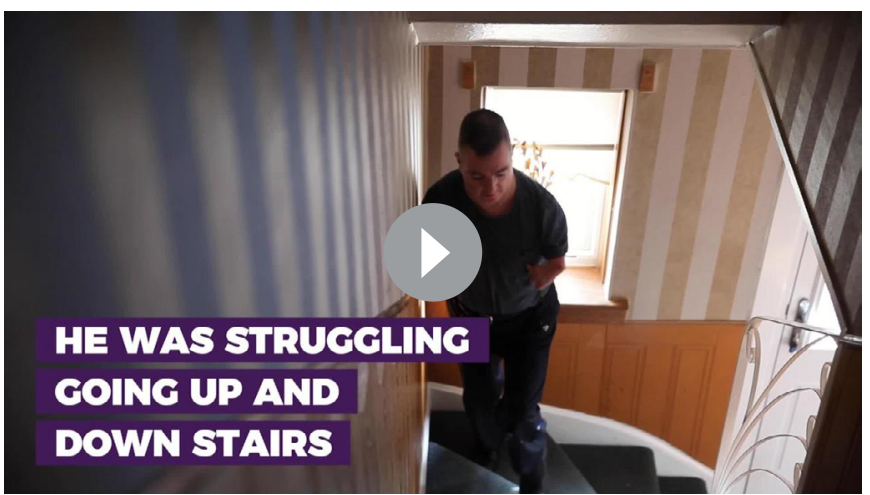

Video 1 Beneficiary climbing stairs.
Table 1 Objective and subjective pretreatment and post-treatment balance test scores and indicators

\begin{tabular}{|c|c|c|}
\hline \multicolumn{3}{|c|}{ Objective and subjective measurements } \\
\hline & Before treatment & After treatment \\
\hline \multicolumn{3}{|l|}{ Balance tests } \\
\hline $\begin{array}{l}\text { Timed Unsupported Steady } \\
\text { Stand } \\
\text { Timed Up and Go Test } \\
\text { Tinetti Test } \\
\text { FES-I-lower score the } \\
\text { better } \\
\text { Ability to manage stairs- } \\
\text { informal measurement }\end{array}$ & $\begin{array}{l}>60 \mathrm{~s} \text { but marked postural } \\
\text { sway } \\
-5 \mathrm{~s} \\
19 / 28 \text { (moderate risk of } \\
\text { falls-11/16 balance and } \\
8 / 12 \text { gait score) } \\
49 / 64 \\
\text { Used whole body to lean } \\
\text { against the stairs in going } \\
\text { both up and down. }\end{array}$ & $\begin{array}{l}>60 \text { s but postural sway } \\
\text { resolved } \\
4 \mathrm{~s} \\
28 / 28 \\
27 / 64 \\
\text { Needed little or no support } \\
\text { from the wall or a rail in } \\
\text { going up and down. }\end{array}$ \\
\hline \multicolumn{3}{|l|}{ Other indicators } \\
\hline $\begin{array}{l}\text { Proximal hip stability } \\
\text { Oxford Muscle Grading } \\
\text { Scale } \\
\text { Verbal Analogue pain scale } \\
\text { for back pain }\end{array}$ & $\begin{array}{l}\text { Positive Trendelenburg on left } \\
\text { hip and a milder weakness on } \\
\text { right hip. } \\
\text { general weakness in left leg } \\
4 / 5 \text { on left hip flexion, seated } \\
\text { quads and seated hamstrings. } \\
7 / 10\end{array}$ & $\begin{array}{l}\text { Significant improvement } \\
\text { with only a very mild } \\
\text { Trendelenburg on the left hip. } \\
5 / 5 \text { on the left leg, but it was } \\
\text { still not as strong as the right. } \\
0 / 10\end{array}$ \\
\hline
\end{tabular}

FES-I, Falls Efficacy Scale International.

faller in that when he lost his balance he was unable to step effectively in any direction with sufficient speed or amplitude to routinely keep his balance though this is a really subjective measure outside the lab. Side-stepping as well as the directional step-up exercises helped address his proximal hip stability issues with muscle strengthening exercises such as specific bodyweight resistance strengthening exercises-sit to stand, step-ups and so on.

Towards the end of the sessions, when encouragement was given for the beneficiary to consider an exercise for the future, he requested that he would rather exercise with others affected by thalidomide embryopathy as he felt self-conscious of his body. The Trust, therefore, tried to see if others in Glasgow could form a group to be led by the physiotherapist. This was unsuccessful. Though swimming would also have been an ideal exercise, the beneficiary felt uncomfortable struggling to take clothes on and off due his upper limb disability. As future exercise was considered paramount to the beneficiary's success in maintaining any progress, the Trust identified a Pilates teacher close to the beneficiary's home who advertised on her website she worked with physiotherapists and approached her on the beneficiary's behalf. Again, once the introduction had been made, a good relationship developed between the therapist and client and the beneficiary continued to progress. In total he received five individual Pilates sessions over 5 weeks.

\section{OUTCOME AND FOLLOW-UP}

The Timed Unsupported Test and Timed get Up and Go Test were not considered very sensitive indicators for the beneficiary as he had a marked postural sway and because he had treated the initial Timed Get Up and Go test as a race (table 1). With an initial score of $0 / 2$ for the 'sternal nudge' in the Tinetti test, he had to be caught after a very light push to the sternum. However, in the final testing he was extremely solid even when given a much stronger push that would test even an average individual. Hence there were marked improvement scores in the Tinetti test, the Falls Efficacy Test and much less reliance on the wall or a rail to go up and down stairs. The verbal analogue pain scale for his back pain had improved from 7 to 0 after four treatment sessions. By the time it had completely finished the beneficiary 


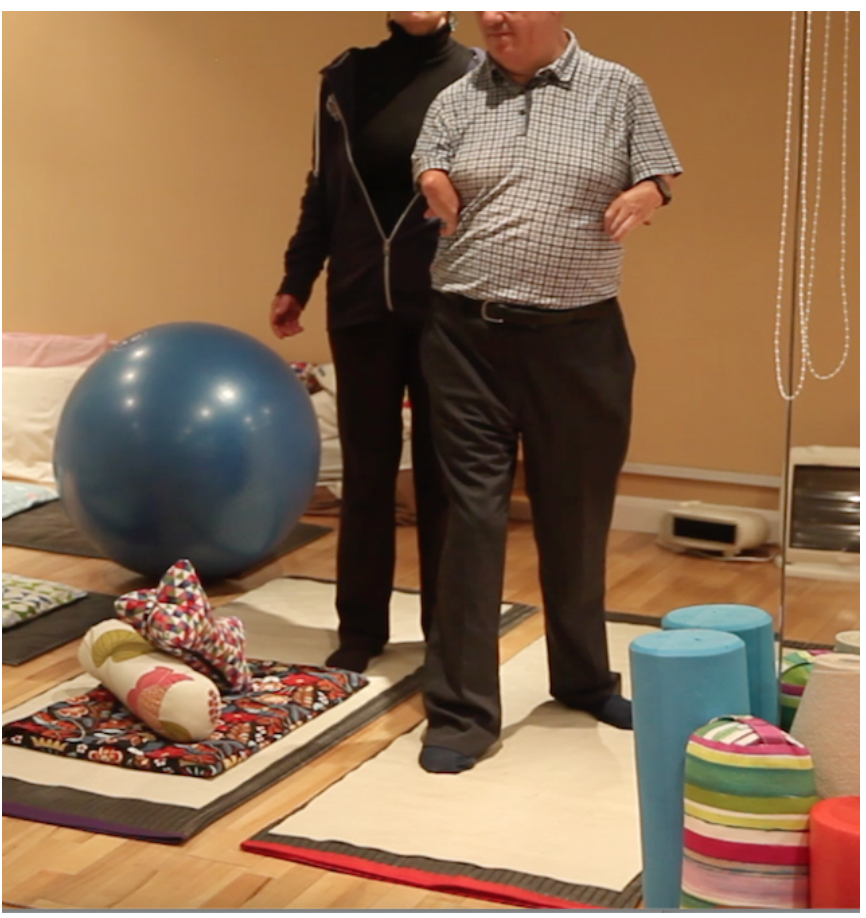

Figure 2 After treatment.

reported noticeable improvement in his low back pain; he felt his posture had improved; he felt able to reach and bend better; he could manage the stairs more effectively; he felt the strength in his legs had improved and, most importantly to him, he felt more confident and able to take up the Pilates. The video company who recorded the beneficiary's progress commented how noticeably the beneficiary's posture and confidence had improved and how much straighter he walked and sat (figure 2). In the middle of the physiotherapy the beneficiary went on a cruise with his wife and reported it to be more enjoyable because he could walk further due to his increased strength and balance. On completing the five sessions of Pilates funded by the Trust, the beneficiary felt very committed to continuing the sessions.

The filmed material was made into a short video to use for assisting other physiotherapists in their work with thalidomide survivors but also to inform other thalidomide survivors of the benefits of physiotherapy, exercise and falls prevention. It was posted on the Trust website in the two different sites. ${ }^{4}$

\section{DISCUSSION}

Due to the beneficiary's damage, the initial physiotherapy assessment and treatment was paramount before the beneficiary could commence taking up exercise for the first time in his life. Not only did it improve the beneficiary's self-confidence to undertake exercise, it also identified causes of pain, allowed correction of abnormal gait and strengthening of existing long-term muscle imbalances from asymmetrical damage. Health messages focus on encouraging exercise and suggest benefit at any stage of life but this fails to take into account the needs of people with disabilities with little thought given to suggesting individual assessment prior to exercise nor to careful consideration of the best form of exercise for the individual. However, without such an assessment, gait abnormalities which become increasingly common with age are not assessed prior to exercise. ${ }^{9}$ Saga, however, does promote physiotherapy in their Get Up and Go leaflet. ${ }^{10}$

\section{Patient's perspective}

I have short arms and shortness of one of my legs. My back pain started in my late 40s. Eventually I struggled to even attempt to go up and down stairs and I did not feel very secure getting on and off buses.

I spoke to the Trust who suggested I contact a physiotherapist. I went to a Trust event. I had never seen Pilates before but wanted to get fitter. I had never done exercise before until I spoke to the physio and then it made sense. The physio came to my house for the sessions and I worked with him for 5 months.

In general after the physio I was a 100\% better, even walking. I was more confident when out and about. I was surprised how quickly it happened, even after the first 2 weeks I was a lot straighter and more upright. I can reach and bend more easily to get things out of the fridge and cupboard.

The Pilates classes went really well. I could not believe they were just round the corner from my house.

I went on holiday during the physiotherapy and it was a joy to go because I was more or less pain free and I could enjoy it. We were walking every day and before the physio I could not have done that. I would have struggled.

I never dreamt of going to a physio. I would have been too embarrassed. But once started the confidence grows. I took things for granted because of the shortness of my leg, that this was the way I walked, putting up with it because nothing could be done. But it is a lot stronger now and I honestly wish I had done this years ago. It is made me more confident.

\section{Learning points}

- Physiotherapy assessment prior to exercise in later life is an important consideration, particularly in those with physical limitations and uneven gait.

- Helping find a suitable exercise for individuals who have never exercised before middle age is fun, sociable and easy for them to take part in, encourages routine and the continuance of the exercise in the future.

- The cost of accessing suitable activity that meets their physical and social needs can be prohibitive to most people living with a disability.

- Careful consideration should be given by Falls services before limiting their services and their information to a specific age range.

The relationship between patient and therapist is paramount to ensuring that an individual continues with physiotherapy and exercise particularly in $1 / 1$ situations. The beneficiary developed a good rapport with both physiotherapist and Pilates teacher; the Pilates teacher's husband, having suffered a spinal cord injury, ensured she was very familiar with helping those with extensive disability. Though initially the Trust aspired for the beneficiary to exercise with others to ensure a social element to the exercise, the Pilates teacher preferred to work with male clients on a $1 / 1$ basis citing different physiques and presenting issues to female clients. She also had access to reformer Pilates equipment as well as mat-based work which was important to help target the beneficiary' $s$ upper limb disability. Though swimming is one of the few cheap exercises for non-weight-bearing activity, it is not unusual for individuals with rare or severe impairments to dislike this form of exercise because of the difficulty and 
additional time involved in undressing and dressing, coupled with their self-consciousness in a bathing suit. There are few suitable alternatives; the alter $G$ treadmill is enjoyed by at least one other beneficiary with severe upper and lower limb damage but all, including 1/1 Pilates, are expensive. The award of the Health Grant by the government has allowed those with thalidomide embryopathy to consider this type of expensive personalised exercise and the beneficiary will be able to use his grant to maintain his progress. ${ }^{11}$ Others with similar disabilities and needs are not so fortunate and perhaps this should be considered part of the cost of disability.

The beneficiary was motivated partly by the Trust seminar on fitness and well-being that included a Pilates taster session. ${ }^{6}$ Though this helped prime the beneficiary ready to undertake a programme, finding an appropriate therapist local to where he lived and allowing the routine to develop before the project was

completed together with the beneficiary enjoying the. sessions were paramount to the goal of the beneficiary continuing to exercise in the future. When the beneficiary contacted the Trust helpline, instead of being given targeted support, an option would have been a tailored leaflet on balance and falls devised by the Trust in response to the research. ${ }^{4}$ In the media, much of the literature on balance and falls seems to be geared to the elderly or those over the age of 60-65, for example, the NHS falls leaflet says 'But all healthcare professionals take falls in older people very seriously because of the significant impact they can have on a person's health'. ${ }^{12}$ NICE guidance itself mentions falls in those over 65 but does at least refer to a younger age group for those at risk inside hospital. ${ }^{13}$ Yet the reasons for an increased risk of falls and how to help apply equally to those who are younger.

Hence it would seem logical to remove comments regarding age from relevant literature or to ensure the literature is inclusive of all adults. This would remove barriers cited in Trust research on falls and balance issues and encourage all ages to seek help from general practitioners and health professionals when at risk of falls. ${ }^{3}$

Acknowledgements The author thanks Fraser Simpson of Simpson physiotherapy and Carol Jacobs of PY Therapies for their help.

Contributors I am the sole author of this article.
Funding The author has not declared a specific grant for this research from any funding agency in the public, commercial or not-for-profit sectors.

Competing interests None declared.

Patient consent for publication Obtained.

Provenance and peer review Not commissioned; externally peer reviewed.

Open access This is an open access article distributed in accordance with the Creative Commons Attribution Non Commercial (CC BY-NC 4.0) license, which permits others to distribute, remix, adapt, build upon this work non-commercially, and license their derivative works on different terms, provided the original work is properly cited and the use is non-commercial. See: http://creativecommons.org/ licenses/by-nc/4.0/.

\section{ORCID iD}

Dee Morrison http://orcid.org/0000-0003-0967-1014

1 Newbronner E, Glendinning C, Atkin K, et al. The health and quality of life of Thalidomide survivors as they age - Evidence from a UK survey. PLOS One 2019:14:e210222

2 Nicotra A, Newman C, Johnson M, et al. Peripheral nerve dysfunction in middle-aged subjects born with thalidomide embryopathy. PLoS One 2016;11:e0152902.

3 Newbronner E. Falls and balance problems Briefing paper, the thalidomide trust, 2017. Available: https://www.thalidomidetrust.org/wp-content/uploads/2016/10/ Falls-and-Balance-Problems-Briefing-Paper-FINAL.pdf [Accessed May 2019].

4 Morrison D. Falls and balance awareness. The thalidomide trust. Available: https:// www.thalidomidetrust.org/health-and-\%20wellbeing/health/falls-and-balanceawareness/ [Accessed May 2019].

5 Kent S. Get yourself active. The thalidomide trust. Available: https://www. thalidomidetrust.org/get-yourself-active/ [Accessed June 2019].

6 Illger S. Fit for the future. The thalidomide trust. Available: https://www. thalidomidetrust.org/news/events/fit-for-the-future/ [Accessed June 2019].

7 Simpson F. Physiotherapy video case study. The thalidomide trust. Available: https:// www.thalidomidetrust.org/physiotherapy-professionals/physiotherapy-video-casestudy/ [Accessed August 2019].

8 NHS. Balance exercises. Available: https://www.nhs.uk/live-well/exercise/balanceexercises/ [Accessed May 2019].

9 NHS. Physical activity guidance for older adults (65+years). Available: www.nhs.uk/ Livewell/fitness/Documents/older-adults-65-years.pdf [Accessed May 2019].

10 Saga. Get up and go, 6 exercises for staying healthy. Available: https://www. csp.org uk/system/files/web_friendly_english_0.pdf [Accessed May 2019].

11 Government. Health grant awarded to victims of thalidomide. Available: https://www. gov.uk/government/news/health-grant-awarded-to-victims-of-thalidomide [Accessed May 2019].

12 NHS. Prevention falls, 2018. Available: https://www.nhs.uk/conditions/falls/prevention/ [Accessed May 2019].

13 National Institute for Health and Care Excellence. Quality statement 1: identifying people at risk of falling, 2017. Available: https://www.nice.org.uk/guidance/qs86/ chapter/Quality-statement-1-Identifying-people-at-risk-of-falling [Accessed May 2019].

Copyright 2020 BMJ Publishing Group. All rights reserved. For permission to reuse any of this content visit

https://www.bmj.com/company/products-services/rights-and-licensing/permissions/

BMJ Case Report Fellows may re-use this article for personal use and teaching without any further permission.

Become a Fellow of BMJ Case Reports today and you can:

- Submit as many cases as you like

- Enjoy fast sympathetic peer review and rapid publication of accepted articles

- Access all the published articles

- Re-use any of the published material for personal use and teaching without further permission

Customer Service

If you have any further queries about your subscription, please contact our customer services team on +44 (0) 2071111105 or via email at support@bmj.com.

Visit casereports.bmj.com for more articles like this and to become a Fellow 